\title{
NCAA Academic Fraud Cases and Historical Consistency: A Comparative Content Analysis
}

\author{
Bradley David Ridpath, Gerald Gurney, and Eric Snyder
}

\begin{abstract}
Academic fraud violations in NCAA Division I sports are considered to be major violations if institutional staff members knowingly are involved in providing fraudulent academic credit for athletes (NCAA, 2014). The purpose of this study is to perform a comparative content analysis of NCAA D-I football and men's basketball academic fraud cases since 1990 using similar sources as the NCAA in gathering information for investigations. The researchers focus on violations of Bylaw 10.1 (b) and compare with similar academic fraud allegations not documented within the NCAA's Legislative Services Database (LSDBi). Findings indicate the most common forms of academic fraud include providing exam answers and/or writing assignments for athletes. Inconsistencies exist regarding the following: disassociation periods for individuals, accrediting letters, institutional probation, informing future athletes of sanctions, and paying of fines. As such, it can be inferred that the NCAA may use Fletcher's Theory of Situational Ethics in its decision making.
\end{abstract}

Intercollegiate athletics has a unique place in American history (Crowley, 2006; Falla, 1983). Oftentimes, the spectacle of commercialized college sports along with the National Collegiate Athletic Association (NCAA) and its member institutions, have been accused of overwhelming the university and diverting its mission of academic primacy (Sack, 2008; Splitt, 2002). The pressure to win games, garner elite prospective athletes, maintain the eligibility and retention of athletes, and generate revenue, ostensibly to benefit the university is frequently used as an impetus to engage in academic fraud and misconduct at the expense of institutional integrity (Marsh, 2014; Ridpath, 2010; Sack, 2008; Sack \& Staurowsky, 1998).

Outside of athletic pressures, institutional employees and the general public often coincide with the belief that intercollegiate athletics are the "front porch" of the university and its existence drives enrollment, branding, and more meaningful alumni relations. As a result, athletics are the first attribute of the university that the public often notices or what they are most familiar with concerning a given institution (Nixon, 2014; Pratt, 2013; Ridpath, 2010; Suggs, 2003). Another result is the perceived notion that having an NCAA Division I athletics department will result in economic benefit for the institution. This economic benefit, if it exists, is largely

Ridpath (ridpath@ohio.edu) is with the Dept. of Sports Management, Ohio University, Athens, OH. Gurney and Snyder are with the Dept. of Education, University of Oklahoma, Norman, OK. 
dependent on football and men's basketball which are the primary commercial revenue generators for the NCAA (Fulks, 2013; Marburger \& Hogshead-Makar; 2003; Nixon, 2014). For example, the current NCAA men's "March Madness" basketball tournament contract is valued at 10.8 billion dollars over 14 years (Jones, 2014). The newly established College Football Playoff (CFP), which is indirectly linked to the NCAA, recently agreed to a 5.64 billion dollar deal over 12 years (Hinnen, 2012). Given the exuberant monetary growth in contractual agreements with the NCAA and its member institution, it is clear that the NCAA's financial solvency and potential existence may now be reliant on the success of big-time Division I men's football and basketball programs.

Recently, a well-publicized academic and athletic scandal involving the University of North Carolina (UNC) garnered the attention of accrediting agencies, major media outlets, institutions, and the federal government. The severity of the academic misconduct sparked a controversy that challenged the core principles of the NCAA whose member institutions claim academic integrity is paramount in college sports. Accordingly, NCAA bylaw 1.3.1 supports this notion by stating that "athletics programs of member institutions are designed to be a vital part of the educational system" and "the athlete as an integral part of the student body" (NCAA 2014). The growing case at UNC includes roughly 1500 student-athletes and 18 plus years of allegations concerning no-show classes that required little to no work. Faculty and athletic staff complicity, unauthorized grade changes, and an ingrained system of eligibility maintenance at UNC unquestionably resulted in an academic disservice to marginal student athletes (Kane, 2014a, 2014b). As a result, the institutions academic reputation has been temporarily degraded by national media outlets as most coverage can be perceived as negative toward institution.

The lack of immediate action by the NCAA's enforcement division regarding UNC, as described by former NCAA Committee on Infractions (COI) Chair Josephine Potuto, has prompted many interested observers to question if the NCAA has arbitrary and inconsistent standards among institutions when adjudicating academic fraud sanctions (Potuto, 2006-2007). Anecdotal evidence suggests that other member institutions have been sanctioned for lesser student-athlete involvement and fewer NCAA violations. While it is understood that the functionality of the association is incumbent on the athletic success and revenue generation of certain member institutions and sports; it is also understood that membership with the association should result in an effective and fair rules enforcement process that prides itself on competitive equity.

This study is grounded in Fletcher's Theory of Situational Ethics (1966). The theory evolved from philosophy and religious studies emphasizing the development of an absolute with a flexible application of the absolute standard to individual situations as decided by those in authoritative positions. The theory presumes that decisions can be influenced by what might bring the most benefit to a particular situation rather than what is known to be correct. While the member institutions view the NCAA bylaw as an absolute, if the NCAA COI takes a situational approach, they reflect on every situation and provide sanctions that keep in mind the impact on the larger association. This situational behavior may result in a lack of equitable decision-making and/or the refusal to consider investigating certain bylaw violations. By excluding situational ethics, consistent investigations and sanctioning of institutions can occur. 
In this study, the researchers examined the consistency of the NCAA COI decisions to adjudicate and sanction institutions regarding academic fraud in the sports of football and men's basketball since 1990. The researchers limited the scope of this review to 1990 due to the sheer number of cases regarding unethical conduct and academic fraud from that date forward. In addition, this time frame was also selected due to a congressionally appointed panels recommended changes to the NCAA enforcement and infractions processes that were adopted post 1990. The conclusions reached by the panel permitted the following: the use of new investigative techniques including tape recording of interviews, the use of legal counsel, and the adoption of changes to the hearing process, including a limited appeals procedure (Due Process and the NCAA, 2004).

Specifically, the examination will focus on those academic fraud cases in Division I football and men's basketball that share similarities with NCAA infractions cases that were not adjudicated by the COI. Much like those adjudicated cases from the NCAA Legislative Services Database (LSDBi), the non-adjudicated cases surface legitimate allegations that violations of NCAA bylaw 10.1(b), Unethical Conduct occurred. The selection of men's football and men's basketball was intentional. First, NCAA Division I football and men's basketball receive the majority of the major media outlet coverage. Second, this attention often times allows for a more critical analysis of reports in comparison with NCAA investigations. Third, a review of all LSDBi cases reveals football and men's basketball violations occurred within 158 of the 368 cases resulting in $43 \%$ of the infraction investigations (NCAA LSDBi, 2015). Lastly, and most important to this study, these two sports support the majority of the revenue enjoyed by all other NCAA member institutions and their existence is vital to the association's financial security (Hinnen, 2012; Jones, 2014).

\section{Literature Review}

The arrangement of playing sports in exchange for a financial scholarship has existed in the NCAA since 1950 (Byers, 1995; Ridpath, 2002; Sack, 2008; Sack \& Staurowsky, 1998). The term "student-athlete" was created by NCAA Executive Director Walter Byers to do two things:

1. Establish a link that college athletes are students first and athletes second

2. Clearly establish that the scholarship is an academic, not athletic award, so as to cover the NCAA in legal battles that may arise over workman's' compensation benefits. (Byers, 1995)

Having a monetary academic award (at least in name) to cover commonly accepted university costs (tuition, fees, room, board, and books) seems like a mutually beneficial arrangement for the institution and athlete. However, in certain instances, the facts are different from the perception that American intercollegiate sport is about education first and athletics second (Ridpath, 2010; Kane, 2014a; 2014 b). The struggle to balance higher education and competitive intercollegiate athletics has been one of significant concern and empirical inquiry for many years (Adler \& Adler, 1991; Briggs, 1996; Crowley, 2006.; Falla, 1983; Hanford, 1974 Ridpath, 2002; Sack, 2008; Savage, 1927). Several attempts have been made by the primary governing body, the National Collegiate Athletic Association (NCAA), 
and other external groups to correct over 100 years of academic integrity issues, including academic fraud, that often become compromised in face of competitive prowess and revenue generation (Ridpath, 2002).

The latest NCAA attempt to restructure the association's enforcement and infractions process in August 2013 reaffirmed the gravity of bylaw violations in intercollegiate sport. The NCAA replaced the former major and secondary violation schedule by creating a hierarchical rating system ranging from Level 1 for major violations (the most egregious challenges to NCAA model) to Level 4 for minor violations (NCAA, 2014). Within this new system, academic fraud violations are considered Level I. This may stem from the extensive interest in the consistency of academic fraud cases due to previous non-action, or at least perceived non-action, by the NCAA concerning academic fraud allegations at certain institutions (Anderson, 2014; Kane, 2014a \& b). Oftentimes there have been controversial decisions by the NCAA with regard to whether cases of academic fraud are investigated, how penalties for academic fraud are adjudicated, and the consistency of those punitive measures among offending institutions. Of late, athletic academic scandals at Auburn University (2006), the University of Michigan (2008), and the University of North Carolina, (2012) have alleged fraudulent classes, top grades and impermissible academic assistance being given to athletes by university personnel (Kane, 2014a; Wetzel, 2008; Thamel, 2006). In each case, there seemed to be collusion with athletic department personnel and a strong probability that fraudulent grades may have affected the eligibility of large numbers of athletes. In spite of these serious allegations, the NCAA enforcement staff declined to investigate and deferred the matter to the institutions.

\section{Academic Fraud and Intercollegiate Athletics}

According to Brown and McCaw (2012), academic integrity is a cornerstone of the NCAA's governance model in that it is based upon the principle that all college athletes satisfy the same academic standards as their non-athlete peers. NCAA violations of academic integrity and academic fraud undermine the purpose of higher education and are a continual area of rules compliance risk.

NCAA Bylaw 10.1-(b), Unethical Conduct, governs a wide range of behavior that includes academic fraud infractions. Ironically no specific bylaw exists that governs or spells out behaviors that constitute academic fraud in the NCAA Manual (Brown \& McCaw, 2012; Infante, 2012; NCAA, 2014). The actual term "academic fraud" is mentioned only once in the entire Division I Manual, but only as a basis for postseason bans. Categories that fall under academic dishonesty by institutional rules, such as cheating, plagiarizing, buying papers, having someone else take tests for athletes, unauthorized grade changes, are likely considered academic fraud by the NCAA, but not always (Infante, 2012). It is important to note that not every instance of academic misconduct related to a college athlete can constitute an academic fraud violation for NCAA compliance purposes (Brown \& McCaw, 2012; Infante, 2012; NCAA, 2014). The process of determining what is academic fraud and what is not can be complicated (Infante, 2012).

Specifically, if there is an allegation of academic misconduct related to an NCAA athlete, the institution is first charged with determining whether the misconduct should be reported to the NCAA as a violation of the Association's bylaws 
(Infante, 2012; Norlander, 2014). Often times this is not an easy scenario considering some of the idiosyncrasies that might be involved concerning intent, university personnel knowledge of the fraud, and if there were any adverse eligibility consequences. In addition, it is documented that often times the institution and NCAA have handled academic issues outside of established institutional review protocol. (Infante, 2012; Gurney \& Willingham, 2014). On September 6, 2000, the NCAA issued an official interpretation that established guidelines for institutions to use in answering this question. This interpretation basically states that there are two tests for academic fraud being an NCAA violation and establishes that an institution "is required to report" a violation of Bylaw 10.1-(b) (the unethical conduct NCAA bylaw that covers academic fraud) to the NCAA in either of two situations:

... any time an institutional staff member (e.g., coach, professor, tutor, teaching assistant) is knowingly involved in arranging fraudulent academic credit or false transcripts for a prospective student-athlete or student-athlete, regardless whether the staff member acted alone or in concert with the prospect or student-athlete.

... any time a student-athlete, acting alone or in concert with others knowingly becomes involved in arranging fraudulent academic credit or false transcripts, regardless of whether such conduct results in an erroneous declaration of eligibility. (Brown \& McCaw, 2012, para 5)

Of special note, the official interpretation is clear in demonstrating that there does not have to be direct involvement of an athletic staff member for the fraud to be considered a major NCAA violation as mentioned above. The definition of a staff member is extremely broad and even includes students and volunteers. Specifically as noted in an October 2001 NCAA Educational Column, "a staff member includes any individual who performs work for the institution or the athletics department, even if the individual is a student at the institution (team managers, athletic trainers) and/or does not receive compensation from the institution for performing such services (e.g., volunteer coaches, undergraduate assistant coaches and graduate assistant coaches)" (Brown \& McCaw, 2012, para 8; Infante, 2012).

This means any involvement by a staff member in academic misconduct must be reported to the NCAA as academic fraud since it meets the definition of the official interpretation. For example, even if an athlete completed most of the work on an assignment or already knew the subject matter of the test for which he was provided answers, this does not excuse a staff member's involvement or eliminate the reporting requirement. In one case the Committee on Infractions (COI) determined that academic fraud occurred at an institution when an athlete used an outline and other material provided by a tutor to compose a paper, as well as when a tutor drafted concluding paragraphs to several papers for an athlete. Similarly, the COI has determined academic fraud when an athlete submitted a rough draft of a paper written by a staff member, even though the athlete received no credit for the rough draft and subsequently wrote the final paper for his grade on a different subject (Brown \& McCaw, 2012). The history of the COI's decisions indicates that any work by another individual which blurs the ability to evaluate the student-athlete's independent work on any academic assignment that is the athlete's responsibility constitutes academic fraud (Marshall University Public Infractions Report, 2001). 
Despite the broad scope of Bylaw 10.1-(b) for unethical conduct, the 2000 NCAA official interpretation establishes that not every instance of academic misconduct related to an athlete constitutes a reportable violation of Bylaw 10.1-(b) (Brown \& McCaw, 2012). The official interpretation states that an institution "is not required to report" a violation if "an athlete commits an academic offense (e.g., cheating on a test, plagiarism on a term paper) with no involvement of an institutional staff member [...] unless the academic offense results in an erroneous declaration of eligibility and the student-athlete subsequently competes for the institution" (Brown \& McCaw, 2012, para 11). This indicates that even if the institution was unaware of cheating by the athlete, if he or she competed for the institution, the athlete was ineligible because a bylaw violation occurred.

The involvement of a staff member with any academic misconduct regarding a prospective incoming athlete also constitutes academic fraud that must be reported. Past major infractions cases such as at Mississippi State University, indicated situations in which prospects transferring from two year institutions attempt to complete a significant number of credit hours in a short period of time through correspondence or on-line courses are an area of particular risk (Mississippi State University Public Infractions Report, 2005). There have also been academic fraud violations due to staff members' involvement with prospects' precollege/welcome week entrance exams and/or tampering with high school educational records. The most highly publicized example of providing fraudulent high school credentials is the allegation that current NBA star Derrick Rose had another person take his college entrance exam so he could gain admission to the University of Memphis (Brown \& McCaw, 2012; University of Memphis Public Infractions Report, 2009).

\section{Academic Fraud-Challenges in Definitions}

Despite the challenges in determining academic fraud and the varying interpretations that exist, the concept of whether the NCAA should involve itself seems very direct and simple. Essentially using existing NCAA bylaws and official interpretations, the two tests for NCAA academic fraud are as follows:

\section{Did the fraud affect the athlete's eligibility?}

2. Did members of the athletic program, administration, or faculty participate in it?

While the NCAA allows institutions great autonomy in regard to establishing institutional policies for addressing academic misconduct, it expects a member institution to abide by the policies it establishes and to consistently apply those policies to athletes and non-athlete students. Specifically, "if an athlete knowingly engages in conduct that violates institutional policies, the institution is required to handle the athlete's academic offense in accordance with established academic policies that are applicable to all students, regardless of whether the violation is reportable under Bylaw 10.1-(b)" (NCAA, 2000, para 5). Therefore, whatever an institution's process for reporting, investigating, adjudicating, and disciplining academic misconduct may be, it is important for the institution to follow that process for athletes and non-athlete students alike. Otherwise, the institution risks facing a potential allegation of an institutional control violation of 
NCAA bylaws even if the underlying academic related conduct does not constitute an academic fraud violation or an institutional control violation (Infante, 2012; Norlander, 2014).

\section{Theoretical Framework}

Intercollegiate sports is a multibillion dollar business that broadcasts continuously on television, fills large stadiums with fans, and celebrates coaches who oftentimes are the highest paid public employees in the state. The pressures from many constituents to field successful teams predicated on academic eligibility of athletes can put stress on a system dependent on winning, and revenue generation (Nixon, 2014; Ridpath, 2010). The result may be the NCAA's COI use of situational ethics in determining sanctions of the NCAA's member institutions for academic fraud violations.

This study is grounded in Fletcher's Theory of Situational Ethics (Fletcher, 1966). As demonstrated in the literature review, there is at least a perception, merited or not, of unfair and unbalanced enforcement with regard to adjudication of academic fraud by the NCAA COI (Due Process and the NCAA, 2004). Fletcher's theory states that what is wrong in one situation may be perceived as right in another depending on the situation and perceived benefit of the outcome (Fletcher, 1966; LaBeff, Clark, Haines \& Diekhoff, 1990). In regards to investigations of academic fraud by the NCAA, the COI enters each decision-making situation fully armed with the ethical views and bylaws of the NCAA and its participating member institutions. Given the existence of NCAA bylaws, each situation should be consistently adjudicated resulting in similar sanctions.

Most empirical research on situational ethics to date has concerned academic cheating by college students (Auer \& Krupar, 2001; LaBeff et al., 1990; McCabe, 1992). McCabe (1992) analyzed responses from more than 6,000 college students who generally felt cheating was wrong but did identify situations when they felt cheating was acceptable. Acceptability was determined by the circumstance or rationalization for the cheating. For example, the students felt cheating was acceptable when: dealing with peer pressures, attempting to please parents, struggling with excessive workloads, and attempting to gain admission into professional schools. To these students, the benefits of cheating outweigh the risk of getting caught. Subsequently, more than two thirds of the respondents admitted to cheating on an assignment or test.

Other empirical studies that discuss situational ethics are found primarily in business, journalism, public relations, government activity, and even archeology. However the literature on situational ethics in college sports is scant and dated, but there are relevant studies that address ethical challenges for coaches and administrators. Previous studies on situational ethics in intercollegiate athletics identified that college sports at the very least has its fair share of ethical issues (Hums, Barr \& Gullion, 1999; Lapchick \& Slaughter, 1989; Stieber, 1991). These studies primarily focus on the ethics of paying or not paying players, racial and gender equity, amateurism, and academics. However, Hums et al. (1999) do specifically note in their study that 'improprieties' and NCAA violations in college sports are a major ethical issue due to the popularity of certain sports. They add that a win at all cost attitude pervades "big time" college athletics and institutions feel pressure 
from various constituencies, including the NCAA, to win and generate revenue. One particular quote stands out in the manuscript, "Coaches may feel the odds of not being caught are in their favor and (institutional and NCAA) administrators may look the other way in order to keep the revenue streams flowing" (Hums et al., 1999, p. 58). This perception and situational decision making is a cornerstone to this study and address many of the same pressures using a different theoretical construct.

The theory of situational ethics is appropriate for use in this study because the NCAA is a member-based association and its infractions and enforcement processes are run primarily by the membership. In essence the enterprise is punishing itself for violation of self-regulated principles. A negative investigation of the association, specifically in football and men's basketball, can unquestionably result in loss of revenue streams, certain institutional probation and scholarship reductions, and loss of competition that negatively impacts television ratings and may violate media contracts. A positive outcome regarding the investigation of a major Division I institution allows the association to function at full capacity, generating revenue, fulfilling contract negotiations, and potentially adding additional sponsorships.

As an example, consider a hypothetical scenario where an athletically prestigious revenue producing NCAA member institution is found to have committed the same bylaw violation as a smaller non-revenue generating institution. A case could be made regarding the importance of protecting the prestigious wealthy institution because of the institution's importance to the legacy of the association. However, the same situation at small non-revenue generating institution could result in amplified sanctions or the "death penalty" with little impact on the association in respect to media coverage and financial solvency. This study using the theorized research questions provides empirical evidence to determine whether such practices are occurring or not.

\section{Research Questions}

The following research questions were the focus of this study:

RQ1. Who are the primary individuals by position involved in Division I football and men's basketball academic fraud violations?

RQ2. What types of academic fraud in Division I football and men's basketball were reported? As an example, the following types are considered academic fraud: cheating, plagiarizing, buying papers, having someone else take tests for athletes, unauthorized grade changes, fake classes, and excess tutoring. While this list is not exhaustive each will be considered in the analysis.

RQ3. Has the NCAA been consistent with regard to existing precedent and application of existing academic fraud standards and rules in Division I football and men's basketball cases?

RQ4. Does the NCAA use situational ethics, based on Fletcher's theory of seeking the perceived best outcome, regardless if the conclusion is correct or ethical, with regard to its adjudication of academic fraud cases? 


\section{Methods}

\section{Content Analysis}

Content analysis of concepts is a widely used method in social, political, psychological, and legal and communication sciences (Weber, 1990). Content analysis has been defined as a systematic, replicable technique for compressing many words of text into fewer content categories based on explicit rules of coding (Berelson, 1952; Krippendorff, 1980; Stemler, 2001; Weber, 1990). It consists of screening any kind of document, such as articles, titles, court cases, and texts to identify key words or terms, which can be grouped according to similarity in meaning (Antrop, 2001). Textual analysis, which is a non-traditional component of content analysis, examines the broad outlines that establish a context for determining the significance of the [case] elements (Barkin \& Gurevitch, 1987). Textual analyses are useful for examining trends or patterns in documents. In this study, data collected from the LSDBi database in additional to media reports can be used to investigate how the NCAA manages and sanctions member institutions in academic fraud cases. The textual analysis will yield a more thorough review of the case terminology by paying attention to the way in which words are used, not just conducting a word count, in essence adding depth to our understanding of how NCAA Committee on Infractions (COI) reports were produced and sanctions were provided to the member institution.

\section{Research Design}

This study is structured as a comparative content analysis of primary and secondary data to draw conclusions to answer the research questions. The researchers conducted an exhaustive investigation of existing Division I football and men's basketball academic fraud cases that dealt with Bylaw 10.1 (b) in the NCAA major infractions database (LSDBi) starting in 1990 and ending in March of 2015. The researchers focused on this time period and Division for several reasons: (a) the accessibility of information for that time period, (b) the number of cases for comparison, (c) the increased commercialization of athletics with skyrocketing television contracts, and (d) the significant changes in NCAA enforcement and infractions procedures for Division I athletics post-1990. This allowed for a more consistent and detailed analysis between and among adjudicated and alleged cases. To compare the findings with cases that were not documented within the database, the authors reviewed newspaper and internet articles regarding highly publicized academic fraud events that failed to receive an NCAA Enforcement Staff investigation and instead deferred to the institution. Specifically, three instances were reviewed: (1) University of North Carolina in 2012, (2) University of Michigan in 2008, and (3) Auburn University in 2006.

\section{Data Collection}

The data collection for this study involved a two-step process. The first step was to identify the frequency of academic fraud cases within the LSDBi database. To do so, the researchers completed the following: (a) Under the "search" tab of the database, the researchers selected the major infractions option; (b) Within the "case 
search" screen, all Division I institutions were selected from the dropdown tab; (c) within the "decision made" option, between two dates was selected and January 1, 1990 and March 15, 2015 were entered; (d) under the "involved sports" option, football and men's basketball were highlighted; (e) lastly, in the text search box, "Academic Fraud" were required terms in the case history. In total, 40 cases were identified. These case files were downloaded into a desktop folder in PDF form (see Table 1).

\section{Table 1 NCAA-Investigated Division I Football and Men's} Basketball Academic Fraud Cases Since 1990

\begin{tabular}{|c|c|c|}
\hline University & NCAA bylaw & Date of reporting \\
\hline Syracuse University & $10.1(b)$ & 2015 \\
\hline Howard University & $10.1(\mathrm{c}) ; 10.1(\mathrm{~d})$ & 2014 \\
\hline University of Miami & $10.1(\mathrm{c}) ; 10.1(\mathrm{~d})$ & 2013 \\
\hline Texas Southern University & $10.1(\mathrm{~d})$ & 2012 \\
\hline University of Central Florida & $10.1(\mathrm{~d})$ & 2012 \\
\hline University of South Carolina & & 2012 \\
\hline Georgia Institute of Technology & & 2011 \\
\hline Arkansas State University ${ }^{a}$ & $10.1(b)$ & 2011 \\
\hline University of Tennessee at Chattanooga & & 2010 \\
\hline University of Southern California & $10.1(\mathrm{~d})$ & 2010 \\
\hline University of Richmond & & 2009 \\
\hline University of Alabama & & 2009 \\
\hline Florida State University ${ }^{a}$ & $10.1(a) ; 10.1(b)$ & 2009 \\
\hline Florida International University & & 2008 \\
\hline University of Louisiana at Lafayette & & 2007 \\
\hline University of Kansasa & $10.1(b)$ & 2006 \\
\hline The Ohio State University ${ }^{\mathrm{a}}$ & $10.1(\mathrm{~b}) ; 10.1(\mathrm{c})$ & 2006 \\
\hline Florida A\&M University & & 2006 \\
\hline Weber State University & & 2006 \\
\hline Baylor University ${ }^{\mathrm{a}}$ & $10.1(b) ; 10.1(c) 10.1(d)$ & 2005 \\
\hline Nicholls State University ${ }^{a}$ & $10.1(b) ; 10.1(c) 10.1(d)$ & 2005 \\
\hline Stony Brook University & & 2005 \\
\hline Texas State University & & 2005 \\
\hline Rutgers State University of New Jersey & & 2003 \\
\hline University of Arkansas & & $\begin{array}{l}2003 \\
\text { (continued) }\end{array}$ \\
\hline
\end{tabular}


Table 1 (continued)

\begin{tabular}{lcc}
\hline University & NCAA bylaw & Date of reporting \\
\hline Marshall Universitya & 10.1 (b); 10.1 (c) & 2001 \\
University of Wisconsin & & 2001 \\
Murray State University & & 2000 \\
Texas Tech Universitya & 10.1 (b); 10.1 (c) 10.1 (d) & 1998 \\
Savannah State University & & 1998 \\
Grambling State University & & 1997 \\
University of Texas at El Paso & & 1997 \\
University of Maine, Orono & & 1996 \\
Bethune-Cookman University & & 1995 \\
Morgan State University & 10.1 (b); 10.1 (d) & 1995 \\
Alcorn State Universitya & $10.1(\mathrm{c})$ & 1994 \\
University of Pittsburgh & & 1993 \\
Syracuse University & & 1992 \\
University of Minnesota, Twin Cities & 10.1 (c) & 1991 \\
University of Florida & & 1990 \\
\hline
\end{tabular}

${ }^{a}$ Cases that were in violation of Bylaw 10.1 (b) were chosen for further investigation

The second step to further disaggregate the data, dealt with violation of a specific NCAA bylaw. The cases were opened and searched for an infraction of Bylaw 10.1 (b) which has historically dealt with academic fraud. During this process 30 of the cases were omitted from the analysis because there was no documentation of Bylaw 10.1 (b), leaving 10 cases. The cases ranged from 12 pages (Arkansas State) to 94 pages in length (Syracuse) ( $M=38$ pages).

To analyze the uninvestigated incidents, the researchers completed a Google search. Specifically, the researchers searched academic fraud and the university name (e.g., academic fraud University of North Carolina) to find sources for analysis. The researchers selected the initial news breaking report and then selected an additional report by a well-known news source (i.e., Huffington Post, New York Times). The 10 cases from the LSDBi database that were in violation of Bylaw 10.1 (b) were extracted and grouped together with the 3 uninvestigated cases. These documents were reviewed to answer the research questions

\section{Analysis of Data}

The analysis began by identifying and developing categories for coding all the cases, newspaper, and journal articles during the timeframe of 1990-2015. This allowed the researchers to review cases that were under the same rules and regulations of the NCAA COI during the 25 year timeframe. 
Since the qualitative information collected from the cases are text based, the critical component of analyzing these data are the coding process. Codes, according to Miles and Huberman (1994) are tags or labels for assigning units of meaning to the descriptive information compiled during a study. Codes often pursue and identify word groupings, phrases, sentences, or entire paragraphs within the document for further investigation. These words or phrases are then amalgamated to better understand similarities and differences between them. For the purposes of this study the entire case or report was analyzed, and coding occurred by hand.

To answer the first and second research questions, a textual analysis was conducted (Barkin \& Gurevitch, 1987). This method was chosen because during the initial reading of the cases, it was found that certain individuals were identified as being involved in the academic fraud. For example, "During the 2007 calendar year, the former director of technology arranged for fraudulent academic credit for the student-athlete." This individual could be categorized into the "administrator" category. An identical procedure was incorporated to answer the second research question pertaining to types of academic fraud. Again, the cases were analyzed and grouped. For example, "In December 2007, the former director of technology changed the student-athlete's final grade in Industrial Safety, TECH 3863" was grouped into the "grade changed" category.

To answer the third research question, the researchers used the findings from the first two questions and completed a thematic analysis using constant comparative methodology (Maykut \& Morehouse, 1994). Each investigated and uninvestigated case was read again and differences in penalties or lack thereof were identified and classified. For example, a sanction that contained a statement such as "Because this case involved academic fraud, the president of the NCAA shall, pursuant to NCAA Bylaw 19.5.7.2, forward a copy of this report to the appropriate regional accrediting agency" was counted as a "letter to accreditor." Throughout this process, development, clarification, and category enhancement continued until new observations failed to assist in answering the research question. For the final research question, the researchers took into consideration all information collected from the three previous questions and applied an objective view regarding Fletcher's Theory of Situational Ethics.

\section{Validity and Reliability}

To check for accuracy of the findings, the researchers employed the following procedures: (1) the data collection procedures were followed by each of the researchers, and the documents to be analyzed were confirmed; and (2) for the non-NCAA cases, triangulation of multiple sources of information were collected to insure coherent sources and aligned findings.

The reliability of the study was confirmed by ensuring the researcher's approaches were consistent throughout the project (Creswell, 2013). As Neuendorf (2002) notes, "given that a goal of content analysis is to identify and record relatively objective (or at least intersubjective) characteristics of messages, reliability is paramount" (p. 141). During the coding process, the researchers discussed the cases $(n=13)$ and intercoder agreement was determined if all three researchers 
agreed on the coding used for the passages. When placed in a Cohen's kappa equation (Cohen, 1960), the resulting score was 1.

\section{Results}

The results of each research question are discussed here, in some cases with exemplars drawn from the cases and supplemental articles.

\section{Individuals Involved in Academic Fraud}

RQ1. Who are the Primary Individuals by Position Involved in Division I Football
and Men's Basketball Academic Fraud Violations? Analysis revealed the following individuals were involved in assisting student-athletes with committing academic fraud: $(n=7)$ Staff Members (i.e., Academic Advisors or learning support specialist), $(n=3)$ Coach (Head or Assistant), $(n=4)$ Student Tutor, $(n=1)$ Graduate Assistant (in the athletics department), $(n=1)$ Booster, $(n=5)$, Administrator (i.e., Dean, Athletics Director, Director of Technology), and $(n=4)$ Faculty Member (see Table 2). Within the COI reports, the titles of individuals were revealed but the official names remained confidential. Within the news reports, the official names of the individuals were revealed, however, for consistency the authors identified those individuals by their title (e.g., faculty, administrator).

For this study, faculty, administrator, and staff involvement was of critical importance because the three uninvestigated instances dealt specifically with these individuals. The search revealed only one of the ten investigated NCAA violations of academic fraud involved a faculty member. In this instance, the COI found the assistant professor at Marshall University had "knowingly provided copies of the final examination in PE 201 (Scientific Foundations of Physical Education) to football student-athletes in advance of the administration of the final examination" (Marshall University Public Infractions Report, 2001, para. 14) In addition, two of the ten COI investigations revealed administrator involvement. At Arkansas State University, the COI found "In December 2007, the former director of technology changed the student-athlete's final grade in Industrial Safety, TECH 3863, without the consent of the teaching professor, who was an adjunct professor in the Agriculture and Technology College" (para. 4). The recent Syracuse report did not result in the sanctioning of an administrator, but indicated a "meeting" that included the director of athletics, director of compliance and the associate provost. The NCAA panel hearing revealed that this was the "first" meeting of its kind for a studentathlete and that there were other "motivations" at play. Specifically, the institutions athletics director indicated the student-athlete "needed basketball" and he hoped the "best defensive player in the country" could play in upcoming games. At the meeting, the individuals "discussed" what courses might be suitable for a grade change for the student-athlete. This subsequently led to the director of basketball operations involvement in violation of bylaw 10.1(b).

Staff involvement occurred in three of the ten COI investigations (i.e., Florida State, Nicholls State, and Texas Tech). The Florida State COI report confirms academic fraud and the improper involvement by an athletic department learning specialist, academic advisor and tutor. Within the Nicholls State report an athletics academic advisor in collaboration with the head basketball and assistant football 


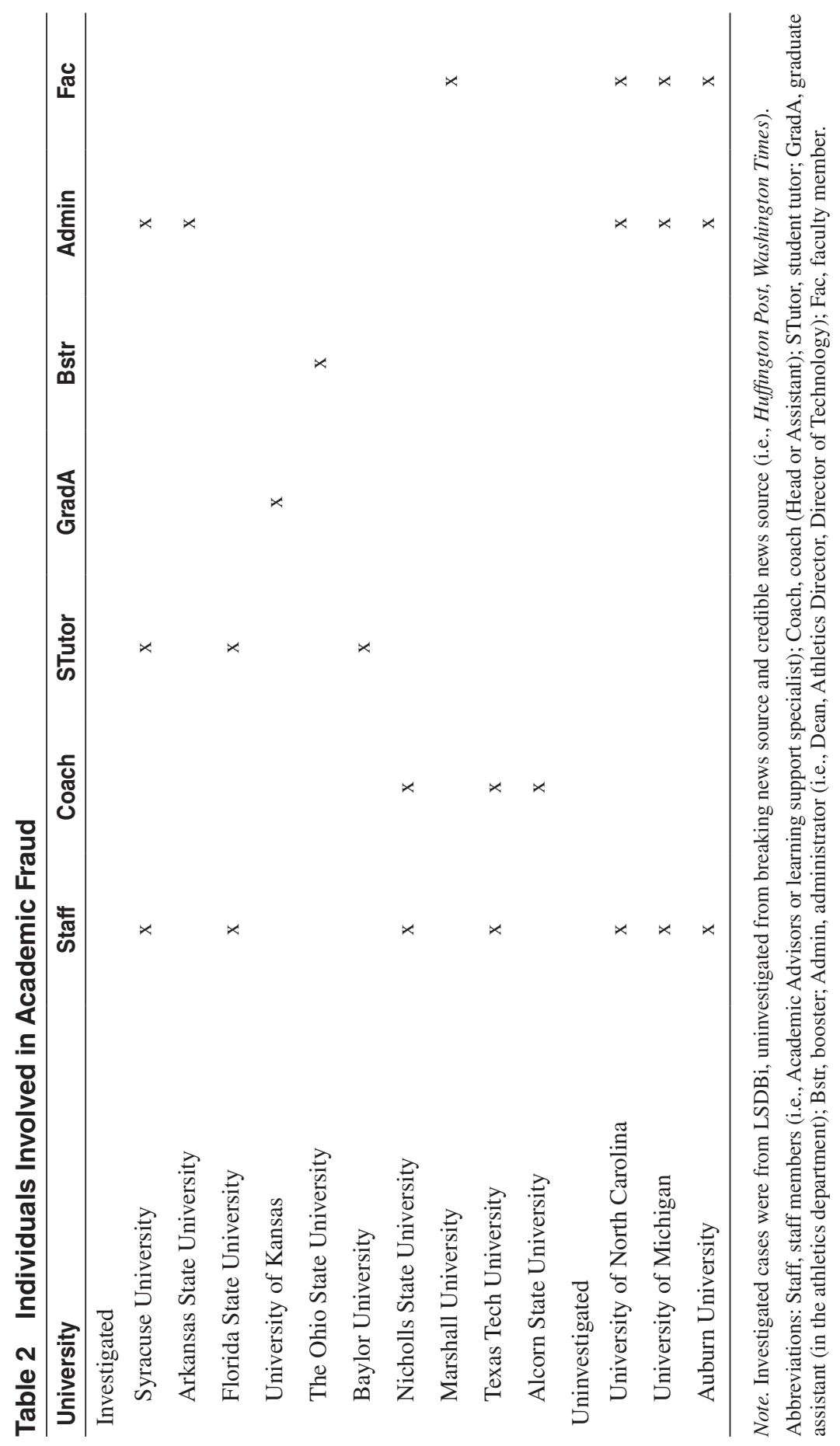


coach committed academic fraud by "providing answers to lesson assignments and exams; falsifying academic documents; and falsely listing as course proctors individuals who acted as conduits by which mailed BYU course materials and exams were provided" (Nicholls State Public Infractions Report, 2005, para. 3). The Texas Tech incident was unique in that the COI was unable to identify the staff member, but found "a member of the athletics department provided the football student-athlete with answers to the Old Testament Survey final examination in order for the student-athlete to memorize the answers before taking the final examination" (Texas Tech Public Infractions Report, 1998, p. 16) The inability of the COI to identify the staff member reveals the difficulty in investigating academic fraud if individuals are not willing to cooperate with the investigation.

The Auburn, Michigan, and UNC incidents revealed direct allegations of involvement of faculty members, administrators, and staff. The Auburn case involved a faculty member from the Sociology Department who taught 120 independent study courses in the fall of 2004 and then 152 independent study courses during the Spring 2005 semester. Many of these courses were taken by studentathletes and were scheduled by their academic advisors or in one particular instance the Director of Student-Athlete Support Services (e.g., administrator). According to the report, the workload for this faculty member was equivalent to "more than three and a half professors" (Thamel, 2006).

The University of Michigan case revealed a psychology professor taught 251 independent studies courses over three years (2004-2007), equating to roughly 28 independent studies courses per semester. Again, there is evidence that staff and administrators were involved in the scheduling of athletes in these courses (Rogers, 2008). More recently, the University of North Carolina reports reveal at least 54 courses, and possibly more, where listed where the instructors did not teach, grades were changed, and faculty signatures were forged. In particular, the former chairman of the African Studies Department in conjunction with the department administrator was identified as the main perpetrator. The extent of staff involvement remains unknown (Martin, 2012).

\section{Types of Academic Fraud}

\section{RQ2. What Types of Academic Fraud in Division I Football and Men's Basketball}

Were Reported? The analysis revealed the following types of academic fraud within Bylaw 10.1 (b) occurred: Provided Exam Answers $(n=6)$, Provided Fraudulent Grades $(n=2)$, Typed and Wrote Papers $(n=5)$, Unauthorized Grade Change $(n=3)$, Fraudulent Scholastic Aptitude Test (SAT) Scores $(n=1)$, and offering Fraudulent Courses $(n=3)$ (see Table 3).

The most common forms of academic fraud reported was providing exam answers to the student-athletes and/or typing and writing the athlete's assignments. The violations at Florida State, Nichols State, and Syracuse consisted of both exam answers and writing of papers. The Ohio State University sanction included a booster and nine other individuals (i.e., family members, neighbors, friends and student-athletes) who confirmed that papers were written for a particular student-athlete. The Alcorn State investigation and sanction was unique in that it dealt with the use of fraudulent SAT scores. In particular, the COI report found the following: 


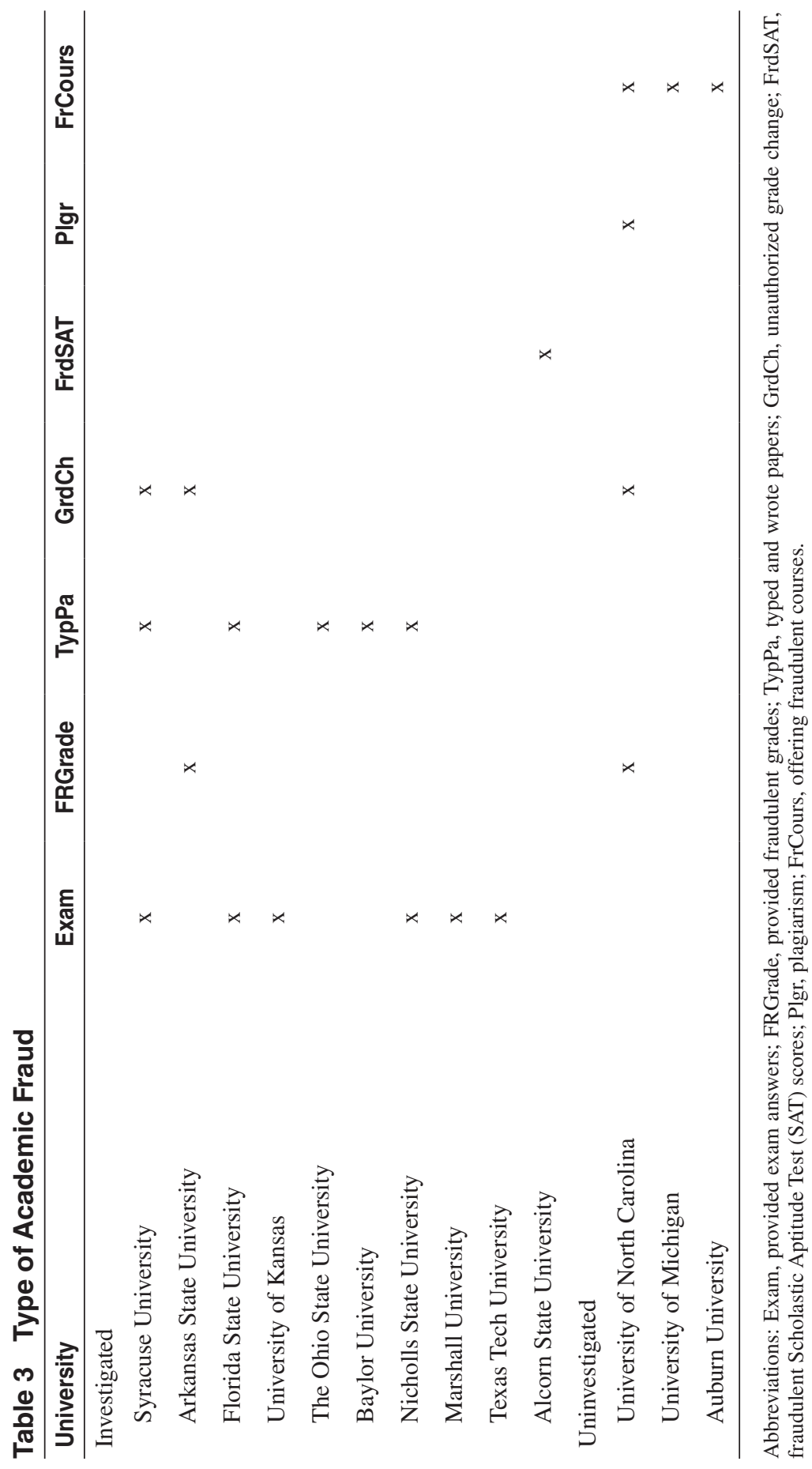


During 1991, seven prospective student-athletes received scores on the Scholastic Aptitude Test (SAT) even though they did not take the examination. As a result of the fraudulent test scores during the 1991-92 academic year five of these students-athletes practices, competed and received athletically related financial aid while academically ineligible under NCAA legislation and two practices and received athletics aid while ineligible. (Alcorn State Public Infractions Report, 1991, p. 4, para 1)

In this instance, the head coach knew the test scores were fraudulent. In addition the coach also instructed one of the young men to provide false and misleading information to the COI (Alcorn State Public Infractions Report, 1991).

When reviewing the types of academic fraud within the uninvestigated cases, fraudulent course offerings were most common. Interestingly, within the ten COI cases, no mention of fraudulent course offerings existed. However, it should be noted that the Nicholls State case did involve athlete enrollment in a Brigham Young University (BYU) distance course and the Texas Tech case involved athlete enrollment in Southeastern College of the Assemblies of God distance courses (Texas Tech Public Infractions Report, 1998). When reviewing the transcripts of the athletes taking these courses, there was noticeable grade inflation. In both of these cases coaches paid for the courses and completed assignments on behalf of the student-athletes.

\section{NCAA Consistency in Penalties}

RQ3. Has the NCAA Been Consistent, With Regard to Existing Precedent and Application of Academic Fraud Standards and Rules in Division I Football and Men's Basketball Cases? In all academic fraud cases adjudicated by the NCAA, the following penalties were provided to each institution in addition to their self-imposed and in some instances conference imposed penalties: (a) public reprimand and censure; (b) athletic department probation; (c) grant-in-aid reduction (sport specific); (d) vacating of wins and changes to all NCAA, conference, and team records; (e) development and submission of comprehensive educational program on NCAA legislation; (f) requirement to submit report to COI regarding comprehensive educational program; (g) file annual compliance reports with COI by a provided date; (h) university president provides letter confirming institutions conformation to all NCAA regulations; and (i) the understanding that all penalties were independent of additional penalties imposed by the NCAA's Committee on Academic Performance (CAP). According to the NCAA website (2014), the central purpose of the CAP is to administer the NCAA Division I Academic Performance Program (APP) which was developed to ensure institutions are dedicated to providing student-athletes with exemplary educational and athletics experiences.

\section{Probationary and Disassociation Periods for Individuals Involved}

In addition to the penalties above, in most instances, individual's that were found to have participated in academic fraud were informed in writing of a probationary period that would subject the individual to Bylaw 19.5.2.2-(1), which can limit 
the individual's athletic related duties or associations for a designated period. The COI provided periods of disassociation ranging from no disassociation to an indefinite period of time depending on the individuals willingness to cooperate in the investigation and the seriousness of the offense.

The recent Syracuse report revealed the COI did not prescribe disassociation periods for any of the constituents involved in the academic fraud portion of the case because the individuals were cooperative (i.e., director of basketball operations, basketball facility receptionist, support services academic coordinators, support service tutor, and part-time tutor). This is contradictory to other reviewed academic fraud cases. However, the COI noted that the infractions records of the individuals would be maintained in the Office of the Committees on Infractions. As such, it is suggested that athletics departments send inquiries to the COI for a list of individuals before hiring.

Additional examples of disassociation periods include a booster's involvement in academic fraud at Ohio State. The letter from the COI required disassociation with the university's athletic department for an "indefinite period of time." The Florida State case resulted in a lesser sanction to the undergraduate student-tutor who was subject to a three-year probationary period. The most puzzling finding when investigating probation and disassociation letters involved the Arkansas State University director of technology who changed an athlete's grades on multiple occasions. According to the COI report "because the former director of technology had no athletically related duties at the institution, he is not at risk to be sanctioned for facilitating the academic fraud" (Arkansas State Public Infractions Report, p. 4, para 2). This direct quote from the report can be viewed as a flaw in the COI pursuit of academic fraud violations in intercollegiate athletics. It also calls to question the ability of committee to ascertain what constitutes "athletically related duties" at an institution. For instance, the Auburn, Michigan, and UNC incidents involved faculty members from the Sociology Department, the Psychology Department, and the African Studies Department. The rationale provided in the Arkansas State University case would prohibit the $\mathrm{COI}$ from sanctioning the faculty. The question remains, could the COI send a letter of disassociation to a faculty member requiring them to disassociate with athletics? While it would be somewhat difficult for the NCAA to sanction a faculty member directly with regard to his/her faculty position, an institution can as a voluntary member of the association enact its own penalties and at the very least limit athletic involvement of the faculty member. As mentioned, action was taken by the institutions in the Michigan and Auburn cases, and a faculty member who was not tenured at Marshall University was fired outright because of alleged involvement in academic fraud (Marshall University Public Infractions Report, 2001). Still it is reasonable to ask, what can the NCAA do with regard to punishment of faculty members who have great protections under tenure and academic freedom and would any NCAA action toward faculty reduce institutional culpability?

\section{Number of Athletes Involved in Academic Fraud}

When reviewing the investigated cases, the number of athletes involved in academic fraud was revealed. This is particularly important when comparing the penalties provided by the NCAA's COI. At Florida State, 61 athletes in roughly 10 sports were involved (this includes football and men's basketball athletes; the specific 
number in each sport was not included in the report). At Nicholls State, 28 athletes, all of whom participated in football or men's basketball were involved. The remaining COI investigations revealed less than 10 athletes per institution were found to have committed academic fraud (see Table 4). While the total number of athletes involved in the Auburn, Michigan, and UNC reports remains difficult to quantify, the estimated number of fraudulent course offerings may display to some extent a legitimate academic fraud concern that would warrant an NCAA COI investigation.

\section{Year of Probation for Institution}

Specific differences did exist regarding the years of probation (YrsPrb) and the degree of egregiousness of the fraud. When reviewing the penalties (Table 4), Baylor University was penalized for a probationary period of five years. The committee's decision to provide such a long probationary period was justified because the institution was a repeat offender and the violation included multiple NCAA rules, not just academic fraud. Florida State and Nicholls State had far more athletes involved in academic fraud but their probation period was less than Baylor's. This again indicates an increased level of scrutiny for repeat offenders.

\section{Paying of Fines}

Three institutions were required to pay fines for violation of the NCAA Bylaws. However, these fines did not pertain to academic fraud and instead were applied for ineligible athletes participating in sporting events. This raises an additional question: If academic fraud occurs and the athlete participates and remains eligible, should the COI impose fines to the institution? For example, a Division I football player could have a paper typed for him in September of 2014, in December, allegations of the fraud are exposed resulting in a COI investigation. Because the student-athlete participated the entire season (which could include a bowl game) should the institution be fined at the current rate of $\$ 500$ per athlete, per contest (Syracuse University Public Infractions Report, p.64, para 2)? If so, would these fines be a deterrent given the multimillion dollar television contracts associated with men's football and basketball?

\section{Future Athletes}

The most recent cases at Syracuse and Arkansas State University were the only case found in the data set to include a requirement to inform prospective athletes that the institution is on probation. A report of the violations is to be provided in advance of a campus visit; "otherwise, the information must be provided before a prospective student-athlete signs a national letter of intent or financial aid document" (Arkansas State Public Infractions Report, p. 8, para 5). This may either be a new trend of the COI for academic fraud cases or a glaring inconsistency placing Syracuse and Arkansas State University at a recruiting disadvantage.

\section{Accreditor}

The following institutions' penalties included a report sent to the appropriate regional accrediting agency: Syracuse University, Arkansas State University, 


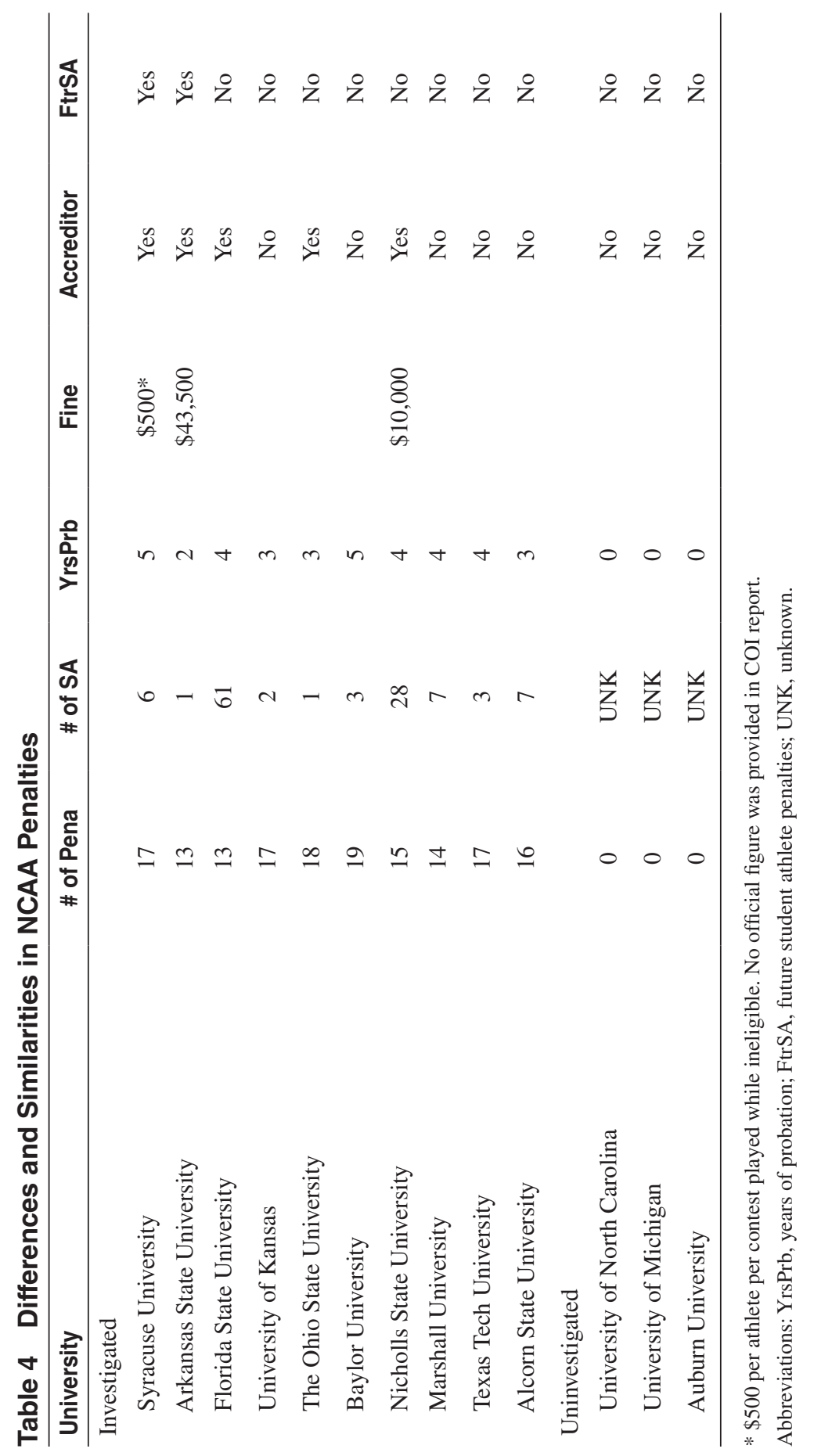


Florida State University, The Ohio State University, and Nicholls State University. In these cases the penalty reads, "Because this case involved academic fraud, the president of the NCAA shall, pursuant to NCAA bylaws 19.5.6.2, forward a copy of this report to the appropriate regional accrediting agency." The findings beg the question as to why other cases such as the University of Kansas, Baylor University, Marshall University, Texas Tech University, and Alcorn State University escaped the reporting requirement.

\section{Consistency of NCAA Sanctions for Academic Fraud Violations}

RQ4. Does the NCAA use Situational Ethics, Based on the Construct of Fletcher's Theory of Seeking the Perceived Best Outcome, Regardless if the Conclusion is Correct or Ethical, With Regard to its Adjudication of Academic Fraud Cases? Using the data it can be inferred that the NCAA may use situational ethics given the lack of consistency between and among academic fraud cases and allegations in other cases. This is justified by the data points and analysis that shows many of the same issues that meet the two tests for academic fraud (staff involvement and effecting eligibility) are alleged and/or present in cases not adjudicated and other cases that were reviewed by the NCAA. Using the theoretical construct of situational ethics, it can also be inferred that the NCAA is choosing when to get involved in academic fraud cases by using a convenient and albeit widely accepted reason of institutional autonomy trumping NCAA rules for its own situational benefit.

The issue becomes that the NCAA has been inconsistent in deciding what cases to investigate with regard to academic fraud and what cases they will leave to the institution. The analysis indicates that the NCAA is also inconsistent in sanctions provided to those who they choose to investigate. As a potential example of the use of situational ethics within the COI decision making, the Arkansas State University case and Florida State University case can be reviewed. How can an institution with one student-athlete receiving a grade change and others competing while ineligible be fined $\$ 43,500$ from an already small athletic budget for Division I standards? Yet, Florida State, Michigan, Auburn, and UNC (with a multimillion dollar athletic budget) received no monetary fine for the involvement of more than 61 students-athletes, and academic specialists are exempt without a fine? Does the situation and impact on the association weigh heavily on the COI and its decision making? Given the empirical evidence provided, it seems logical to assume that the COI does take into consideration the institutions it will be investigation and sanctioning.

\section{Discussion}

The results of the study indicate that inconsistencies do exist regarding the sanctioning of institutions for academic fraud violations. The decision-making is likely based on the particular situation that takes into consideration institutional and individual utility to the NCAA. This is similar to the Hums et al. (1999) findings that decision making in athletics with regard to improprieties are a serious ethical 
issue as decision making for certain popular sports often can be different depending on the situation and perceived benefits to various constituencies. The NCAA $\mathrm{COI}$ is inconsistent regarding which institutions to investigate considering the omission of investigations at UNC, Michigan, and Auburn. While it is reasonable to expect institutions to handle cases involving academic fraud issues; it is clear that the uninvestigated cases contain strikingly similar elements to those cases that were adjudicated by the COI.

The result of such inconsistencies is increased scrutiny toward the NCAA's enforcement wing. Many critics and media members have accused the NCAA of turning a blind eye to the UNC case when the violations are clear (Kane, 2014a $\&$ b). This critique is warranted based on the evidence presented in this study. At UNC many students - some athletes, some not-were found to have participated in no-show classes and/or courses within the Department of African and AfroAmerican Studies. The Raleigh News \& Observer wrote that it was "an academic scandal that spanned at least 14 years and potentially more than 50 classes. Many of those enrolled were athletes" (Kane, 2014b, para 4). This also included several unauthorized grade changes for athletes and non-athletes alike. The allegations and findings of fact in the UNC case offer several elements found to be academic fraud in past NCAA major infractions cases, including potential direct involvement of at least 2 university staff members and indirect involvement of several others, who had ties to the athletic department as boosters, if not more in perpetuating the fraud (Anderson, 2014; Kane 2014a \& b).

Whether this was academic fraud by NCAA standards or not has been subject to intense public debate in the media and on fan message boards. However, using the definitions of academic fraud, the official interpretation discussed earlier and past adjudicated cases, it seems likely that the action constitutes at least a prima facie case of academic fraud that must be investigated by the university and the NCAA. At the very least these instances included the possibility of fraudulent eligibility declarations. The University of North Carolina up to this point has largely avoided significant NCAA punishment for these fraud allegations. After more than a half dozen internal and external investigations, including an initial review by the NCAA, the stance of the university has been to acknowledge that there were problems, however since non-athletes and athletes alike received the impermissible benefits; the scandal was not a scheme solely to benefit athletic eligibility (Kane, 2014a \& 2014b; Martin, 2012). The university called it an academic, not an athletic scandal, which according to the university was worse than it just being a scheme to benefit athletic eligibility (Martin, 2012).

In the midst of public outrage, a reopened institutional investigation, and the cooperation of key participants in the fraud; the NCAA decided in the summer of 2014, to reopen its investigation (Ganim, 2014). To many observers it appeared the entire university was being used as a sacrificial lamb to protect the brand of the athletic department and basketball titles won using potentially academically ineligible players (Lyall, 2014). Even NCAA president Mark Emmert admitted that the UNC case hinges on whether athletes' eligibility was affected or if the fraud was intended to benefit the athlete specifically, but only one scenario needs to be present for it to be an NCAA violation (Barbour, 2012). Others have responded that the NCAA has given a license to all schools to allow their students-athletes to receive benefits by allowing the general student-body access to the fraudulent 
activities. As another example of Fletcher's Theory of Situational Ethics it can be argued that the University of North Carolina and the NCAA were influenced by what was perceived to be the best outcome for the overall institution and by extension the NCAA, even if that meant that the reputation of the entire university was sacrificed to protect the athletic brand.

While all of the aforementioned adjudicated cases have similarities to cases not investigated by the NCAA, one academic fraud case where the NCAA sanctioned the offending institution (Marshall University) mirrors the North Carolina and other aforementioned non-adjudicated cases more closely. It concerned allegations of assigning high grades to all students in the class to conceal the appearance of academic fraud. According to the Marshall University NCAA Public Infractions Report, in 2001 an assistant professor of Exercise, Sport Sciences, and Recreation, who also served as a volunteer athletic trainer in the athletic department, arranged for fraudulent academic credit when he provided an advanced copy of an exam to football athletes in the form of a study guide to bring up their grades. When it became known that the security of the examination was breached and other students, including other athletes found out that the test security was compromised, the professor attempted to correct the problem and cover up his involvement by assigning "A" grades to all students in the class. This case directly correlates with the current UNC case in that

1. There was no evidence that the Professor acted in concert with athletics or under the direction of the athletics department. He stated that it was his decision alone to make the test available and he claimed he also gave it to some non-athletes. While this does correlate with the UNC case, there exists ample evidence via emails and other direct contact that the UNC athletic department communicated directly with faculty members and at least one department administrator to discuss placement and/or grade changes in classes that were later determined to be fraudulent

2. The benefit of the A on the final exam was afforded to every student in the class, not just the athletes. While it was possible an attempt to cover up some wrongdoing, it was a solution that was approved by the Dean of the College due to the fact that it could not be determined which students actually had access to the test before the exam. According to the Dean, this type of decision was not uncommon and was well within the purview of his positional authority

3. To counter the potential negative effect of the class on eligibility of athletes, the athletic department had all athletes enroll in the next immediate summer session and take a legitimate course to make up for the fraudulent one whether it was needed or not for eligibility purposes. In essence the fraud was mitigated for the athletes at all levels, but the NCAA still determined it was academic fraud and a violation of NCAA rules.

For Marshall University and its subsequent sanctions it would appear that there are some inconsistencies with its punishment compared with allegations at schools like North Carolina, Michigan, and Auburn and calls into question the ethical and situational decision making of the COI. The specifics in the Marshall case concerned one class and one professor where it was not proven if he acted alone or in concert with the athletic department. In addition the university issued 
a decision that all students, including non-athletes, received the same grade and that was entirely within the scope of a Dean's discretion and authority. The university also felt that there were no eligibility issues because the athletes had to take another class in a summer session to mitigate the possible fraud that could apply to NCAA and institutional rules in the questionable class. Given that the UNC case concerns potentially hundreds of fraudulent courses and grade changes involving predominantly athletes along with institutional involvement, it is not a difficult conclusion to question the NCAA's consistency when it comes to enforcing academic fraud cases.

Moreover, the NCAA COI tellingly stated the following in the Marshall public infractions report. This strong language gives one pause to examine why the same standards are not applied to all institutions accused of academic fraud:

One consequence of the fraud was that the exam was rendered incapable of measuring or testing with any certainty the football student-athletes' knowledge of the subject matter. Moreover, the fraud eliminated the ability to make comparative assessments of student achievement in the class . . . At a minimum, therefore, students at the top of the class had their course work and achievement devalued by receiving grades no better than those students in jeopardy of failing and conversely, student-athletes in jeopardy of failing were able to pass the course without demonstrating that their work merited a passing grade. (Marshall Public Infractions Report, 2001, para 20)

This standard would seem to tie neatly to the UNC case, among others, given that there has been no additional class requirements for the athletes or non-athletes enrolled in the fraudulent courses and there is strong evidence of institutional involvement. Still there has been no mention of coursework being devalued or knowledge not being appropriately assessed in the UNC case by the NCAA up to this point even though in this case the athletes and non-athletes are allegedly being treated equally. In comparing these two cases, the NCAA again appears to be demonstrating situational ethics with regard to potential punishment, or lack thereof, for North Carolina. Candidly, UNC is much more of a valuable property to the NCAA mechanism and revenue generation than Marshall University and it seems to be clear by the NCAA thus far dodging any significant punishment for unethical conduct and academic fraud for UNC.

While members of the NCAA ostensibly expect consistency in rules enforcement, the NCAA may have been influenced by situational ethics in its application of academic fraud issues. To our knowledge there has not been an overall analysis of academic fraud cases such as this. While there have been accusations of unfairness by the NCAA in application of major infractions penalties, academic fraud in athletics strikes at the core of the higher educational mission and justification for intercollegiate athletics programs. The findings derived from having institutions investigate their own academic fraud cases may lead to an application of self-serving situational ethics and result in further ethical violations. Ultimately the NCAA should investigate all academic fraud cases without the flexible application and interpretation of the rules and established elements of athletic academic fraud. By doing so, member institutions and the public can be reasonably assured the process is fair and even-handed as advertised by the NCAA (Due Process and the NCAA, 2004). 
As an alternative to mitigate disgruntled feelings toward the association, the NCAA should document publically why a specific case of academic fraud was not investigated by the COI if evidence calls for such. A file placed on the association's website could provide the general public, athletic department personnel, and university leadership with documentation and procedural accuracy that allows for full transparency and education regarding the topic. This suggestion will not only assist the NCAA in reemphasizing the importance of academics in higher education but it will provide those who follow intercollegiate athletics with a feeling that competitive equity can still exist within the organization.

\section{Limitations of Study}

There are several limitations in this study. First, the researchers are drawing conclusions based on existing NCAA data and media reports. It is important to note that while many NCAA investigations are started via media reports and outside sources, there is still a real possibility that many potential fraud cases were not identified within the LSDBi database for the scope of this study. For example, when reading the nine investigated COI cases, the reports discussed the Minnesota Case 1999, University of Utah 2003, and Baylor Case, 1995. Each of these cases dealt with football and men's basketball team violations of academic fraud. One reason behind their inability to surface during data collection may have been the database classification of "major" and "secondary" violations. Because these cases were not returned when completing the LSDBi search as outlined in the data analysis protocol, they were not included in the analysis. Second, although the study above was specific to Division I men's football and basketball, it would be helpful to examine other cases from all Divisions because important information may emerge.

Third, caution should be taken in generalizing the findings of the study as each institution's case is different. With that being said when fraud allegations are present along with the stated NCAA criteria for academic fraud being alleged, cases should be consistently and thoroughly investigated by the NCAA without regard to athletic or institutional prestige. Fourth, while the facts of the cases are presented in the results/findings. The use of Fletcher's Theory of Situational Ethics does pose challenges. For instance, interpretation of differing standards needs to be confirmed through interviews with members of the COI. The assumption that the individuals purposively treated the cases differently is inappropriate even though the empirical evidence from this study suggests that certain institutions were held to differing standards. Finally, it should be mentioned that there is no accurate way to establish content validity of the material from the database or the media reports. For example, the recent release of the Weinstein Report has confirmed the accuracy of the UNC incident in addition to facts not mentioned in media articles.

\section{Future Research}

Based on the conclusions drawn, the researchers made the following recommendations for further research regarding NCAA investigations of academic fraud. It is suggested that future research includes conducting interviews with COI members 
regarding the intent of the investigations and rationale for sanctions. Future research could include the development of a survey instrument to measure the athletic department personnel perceptions of NCAA handling of academic fraud cases. Further, conducting the study at different levels of intercollegiate athletic competition (i.e., Division II, Division III, etc.) could yield different results. It would also be appropriate to investigate if differences exist in academic fraud adjudications between revenue and non-revenue sports. Finally, future research could investigate ways to educate the COI and the NCAA's member institutions regarding academic fraud violations by creating an educational model.

\section{References}

Adler, P.A., \& Adler, P. (1991). Backboards \& blackboards: College athletes and role engulfment. New York: Columbia University Press.

(1994). Alcorn State University public infractions report. Indianapolis, IN: National Collegiate Athletic Association.

(2011). Arkansas State University public infractions report. Indianapolis, IN: National Collegiate Athletic Association.

Anderson, R. (2014). Tarnished heels: How unethical actions and deliberate deceit at the University of North Carolina ended the Carolina way. Rock Hill, SC: Strategic Media Books, LLC.

Antrop, M. (2001). The language of landscape ecologists and planners: A comparative content analysis of concepts used in landscape ecology. Landscape and Urban Planning, 55(3), 163-173. doi:10.1016/S0169-2046(01)00151-7

Auer, N.J., \& Krupar, E.M. (2001). Mouse click plagiarism: The role of technology in plagiarism and the librarian's role in combating it. Library Trends, 49(3), 415-432.

Barbour, B. (2012, October 1). Emmert: UNC not clear yet. SBNation. Retrieved from http://www.chatsports.com/north-carolina-tar-heels/a/Emmert-UNC-Not-ClearYet-2-6565569

Barkin, S. M. \& Gurevitch, M. (1987). Out of work and on the air: Television news and unemployment. Critical Studies in Mass Communication, 4(4), 1-20.

(1995). Baylor University NCAA public infractions report. Indianapolis, IN: National Collegiate Athletic Association.

Berelson, B. (1952). Content analysis in communication research. Glencoe, Illinois: Free Press.

Briggs, C. (1996). Differences in degree aspirations and attainment outcomes between football, basketball, and other intercollegiate athletes. Paper presented at the annual meeting of the Association for the Study of Higher Education, Memphis, TN. (ERIC Document Reproduction Service No. 402832).

Brown, S., \& McCaw, C. (2012, August 30). Reporting violations of academic fraud in the NCAA compliance context. Retrieved from http://www.icemiller.com/ ice-on-fire-insights/publications/reporting-violations-of-academic-fraud-in-thencaa/\#sthash.2scBB3Q2.dpuf

Byers, W. (1995). Unsportsmanlike conduct. Ann Arbor, MI: The University of Michigan Press.

Cohen, J. (1960). A coefficient of agreement for nominal scales. Education Psychology Measurement, 20, 37-46.

Crowley, J. (2006). In the arena: The NCAA's first century. Indianapolis, IN: NCAA. Retrieved from http://www.ncaapublications.com/productdownloads/AB06.pdf

Creswell, J. (2013). Research design: Quantitative, qualitative, and mixed methods approaches (4th ed.). Sage Publications. 
Due process and the NCAA (2004, September 14). Hearing before the Subcommittee on the Constitution of the Committee on the Judiciary, House of Representatives, 108th Congress. Retrieved from http://www.house.gov/judiciary

Falla, J. (1983). The NCAA: The voice of college sports. Mission, KN: NCAA.

Fulks, D.L. (2013). Revenues and expenses of NCAA division I intercollegiate athletic programs report: 2004-2012. Indianapolis, IN: NCAA.

Fletcher, J.F. (1966). (Vol. 150. Situation ethics: The new morality. London: SCM Press.

Ganim, S. (2014, July 2). NCAA reopens paper class investigation. CNN.com. Retrieved from http://www.cnn.com/2014/06/30/us/university-of-north-carolina-paper-class/

Gurney, G., \& Willingham, M. (2014, July 18). Academic fraud, athletes and faculty responsibility. Inside Higher Ed. Retrieved from http://www.insidehighered.com/ views/2014/07/18/professors-must-take-academic-fraud-among-athletes-more-seriously-essay\#ixzz39iqH7wKi

Hanford, G. (1974). The need for a feasibility study of intercollegiate athletics. Washington, DC.: American Council on Education.

Hinnen, J. (2012). ESPN reaches 12-year deal to air college football playoffs. CBS sports. Retrieved from: http://www.cbssports.com/collegefootball/eye-on-college-football/21083689/espn-reaches-12year-deal-to-air-college-football-playoffs

Hums, M.A., Barr, C.A., \& Gullion, L. (1999). The ethical issues confronting managers in the sport industry. Journal of Business Ethics, 20(1), 51-66. doi:10.1023/A:1005951720456

Infante, J. (2012, September 12). Rejected NCAA proposal makes UNC case more complex. Athelticscholarships.net. Retrieved from: http://www.athleticscholarships. net/2012/09/12/rejected-ncaa-proposal-unc-case-complex.htm

Jones, T. (2014, March 30). College athletics: NCAA under growing scrutiny in courts. Columbus Dispatch. Retrieved from http://buckeyextra.dispatch.com/content/stories/2014/03/30/ncaa-under-growing-scrutiny-in-courts.html

Kane, D. (2014a, June 6). 2005 UNC champs relied on suspect classes, records show. Raleigh News \& Observer. Retrieved from http://www.newsobserver.com/news/local/education/ unc-scandal/article10332632.html

Kane, D. (2014b, April 15). Deborah Crowder's story could bring NCAA investigators to UNC. Raleigh News \& Observer. Retrieved from http://www.newsobserver. com/2014/04/15/3787302/deborah-crowders-role-in-unc-scandal.html

Krippendorff, K. (1980). Content analysis: An introduction to its methodology. Newbury Park, CA: Sage.

LaBeff, E., Clark, R., Haines, V., \& Diekhoff, G. (1990). Situational ethics and college student cheating. Sociological Inquiry, 60, 190-198. doi:10.1111/j.1475-682X.1990.tb00138.x

Lapchick, R.E., \& Slaughter, J.B. (1989). The rules of the game: Ethics in college sport. New York: Simon \& Schuster.

Lyall, S. (2014, April 26) Reporter digging into scandal hits a university's raw nerve: University of North Carolina is at odds with a Raleigh newspaper. New York Times. Retrieved from http://www.nytimes.com/2014/04/27/sports/reporter-digging-into-scandal-hits-auniversitys-raw-nerve.html?_r=0

Marburger, D.R., \& Hogshead-Makar, N. (2003). Is Title IX really to blame for the decline in intercollegiate men's nonrevenue sports? Marquette Sports Law Review, 14, 65.

Marsh, G. (2014, May 27). 'Friendly faculty': The quiet danger to athletics programs. The Chronicle of Higher Education. Retrieved from http://chronicle.com/article/FriendlyFaculty-the-Quiet/146775

Martin, J. (2012, December 19) The University of North Carolina at Chapel Hill academic anomalies review: Report of Findings. Retrieved from http://www.unc.edu/news/12/ UNC-Governor-Martin-Final-Report-and-Addendum.pdf Marshall University NCAA public infractions report. (2001). Indianapolis, IN: National Collegiate Athletic Association. 
Maykut, P., \& Morehouse, R. (1994). Beginning qualitative research: A philosophic and practical guide. London: The Falmer Press.

McCabe, D.L. (1992). The influence of situational ethics on cheating among college students. Sociological Inquiry, 62(3), 365-374. doi:10.1111/j.1475-682X.1992. tb00287.x

Miles, M. \& Huberman, A. (1994). Qualitative data analysis: An expanded sourcebook. Sage: Los Angeles.

(2005). Mississippi State University NCAA public infractions report. Indianapolis, IN: National Collegiate Athletic Association.

NCAA. (2014). Division I Committee on Academic Performance duties \& responsibilities. NCAA.org. Retrieved from: http://www.ncaa.org/governance/committees/division-icommittee-academic-performance-duties-responsibilities

NCAA Division I Manual (2013-14). Indianapolis, IN: National Collegiate Athletic Association.

NCAA. (n.d.). Amateurism. NCAA.org. Retrieved from http://www.ncaa.org/amateurism

Neuendorf, K.A. (2002). The content analysis guidebook. Thousand Oaks, CA: Sage.

(1996). New Mexico State University NCAA public infractions report. Indianapolis, IN: National Collegiate Athletic Association.

(2005). Nicholls State University NCAA public infractions report. Indianapolis, IN: National Collegiate Athletic Association.

Norlander, M. (2014, April 16). NCAA could change penalties for academic cheating. Retrieved from http://www.cbssports.com/collegebasketball/eye-on-college-basketball/24528941/report-ncaa-could-change-guidelines-on-punishment-for-academiccheating

Nixon, H. (2014). The athletic trap. Baltimore: Johns Hopkins University Press.

(2006). The Ohio State University NCAA public infractions report. Indianapolis, IN: National Collegiate Athletic Association.

Potuto, J. (2006-2007). Academic misconduct: Athletics academic support services, and the NCAA. Kentucky Law Journal (Lexington, Ky.), 95, 447-480.

Pratt, A.N. (2013). Integrated impression management in athletics: A qualitative study of how NCAA Division I athletics directors understand public relations. International Journal of Sport Communication, 6(1), 42-65.

Ridpath, B. (2002). NCAA Division I student athlete characteristics as indicators of academic achievement and graduation from college. Published Dissertation, West Virginia University. Ann Arbor, MI: Pro Quest

Ridpath, B. (2010). Perceptions of NCAA Division I athletes on motivations concerning the use of specialized academic support services in the era of the academic progress rate. Journal of Issues in Intercollegiate Athletics, 3, 253-271.

Rogers, J. (2008, March 16). University of Michigan athletes steered to professor. MLive.com. Retrieved from http://www.mlive.com/wolverines/academics/stories/index.ssf/2008/03/ athletes_steered_to_prof.html

Sack, A. (2008). Counterfeit amateurs. State College, PA: Penn State University Press.

Sack, A., \& Staurowsky, E. (1998). College athletes for hire: The evolution and legacy of the NCAA's amateur myth. Westport, CT: Praeger.

Savage, H. (1927). Carnegie foundation report: Bullet twenty three. Boston: The Merrymount Press.

Splitt, F. (2002). Reclaiming academic primacy in higher education. Chicago: Northwestern University Press.

Stemler, S. (2001). An overview of content analysis. Practical Assessment, Research \& Evaluation, 7(17), Retrieved from http://PAREonline.net/getvn. asp?v= $7 \& n=17$.

Stieber, J. (1991). The behavior of the NCAA: A question of ethics. Journal of Business Ethics, 10(6), 445-449. doi:10.1007/BF00382827 
Suggs, W. (2003, May 2). Sports as the university's front porch? The public is skeptical. The Chronicle of Higher Education. Retrieved from http://chronicle.com/article/Sports-as the-University-s/11599

(2015). Syracuse University Public Infractions Report. Indianapolis, IN: National Collegiate Athletic Association.

(1998). Texas Tech University NCAA public infractions report. Indianapolis, IN: National Collegiate Athletic Association.

Thamel, P. (2006, 14 July). Top grades and no class time for Auburn players. New York Times. Retrieved from http://www.nytimes.com/2006/07/14/sports/ncaafootball/14auburn. $\mathrm{html}$ ?pagewanted=all\&_r=0

Weber, R.P. (1990). Basic Content Analysis (2nd ed.). Quantitative applications in the social sciences. Newbury Park, CA: Sage.

Wetzel, D. (2008, September 24). NCAA naps during golden age of cheating. Retrieved from http://sports.yahoo.com/news/ncaa-naps-during-golden-age-050500703-ncaaf.html 